\title{
EFEKTIFITAS PELATIHAN TATA RIAS PENGANTIN SUNDA PUTRI DI LKP MUSTIKA KABUPATEN CIANJUR
}

\author{
${ }^{1}$ Lina Yuningsih ${ }^{2}$ Dani Supriyadi Sahlan \\ 1,2 IKIP Siliwangi \\ ${ }^{1}$ linayuninsih22@gmail.com, ${ }^{2}$ danisahlan777@gmail.com
}

\begin{abstract}
ABSTRAK
Penelitian ini dilatarbelakangi oleh relatif rendahnya peranan masyarakat dalam upaya melestarikan budaya tradisioanl daerah dalam tata rias pengantin Sunda Putri.. Tujuan dalam penelitian ini adalah Untuk mendeskripsikan kondisi objektif, proses pelaksanaan, efektivitas proses penyelenggaraan keterampilan tata rias pengantin sunda putri di LKP Mustika Kabupaten Cianjur. Penelitian ini menggunakan pendekatan deskriftif kualitatif sedangkan metode pengumpulan data yang digunakan dengan wawancara,observasi dan studi dokumentasi. Sedangkan yang menjadi subjek penelitian adalah peserta pelatihan tata rias pengantin pada LKP Mustika Kabupaten Cianjur. Hasil dari penelitian ini adalah hal ini diketahui dengan terpenuhinya kriteria keberhasilan dalam sebuah konsep pelatihan/pembelajaran. Kriteria keberhasilan program pelatihan ketermpilan Tata Rias Pengantin Sunda Putri itu berhubungan dengan dua hal, yaitu: Dari segi proses (by process), Kriteria keberhasilan dari segi hasil (by product). Berdasarkan penelitian diperoleh kesimpulan efektivitas pelatihan tata rias pengantin sunda putri memberikan peranan yang signifikan dalam melestarikan tata rias di Kabupaten Cianjur. Rekomendasi penelitian agar dikembangkan penelitian berikutnya untuk menemukan faktor-faktor lain yang mempunyai pengaruh terhadap pelestarian tata rias pengantin sunda putri dalam upaya mempertahankan kelestarian budaya daerah sebagai salah satu kebudayaan nasional.
\end{abstract}

Kata Kunci: Tata rias pengantin sunda putri, Efektivitas Pelatihan

\section{PENDAHULUAN}

Secara psikologis perempuan, sebagaimana laki-laki, membutuhkan aktualisasi diri demi pengembangan dirinya dan sesuatu yang pada akhirnya juga berdampak positif terhadap pengembangan umat manusia pada umumnya. Berdasarkan proyeksi BPS (Anwar, 2007: 7), "perempuan Indonesia pada tahun 2000 sebanyak 105.266.200 jiwa (50.23\%) dari total penduduk 210.485.600 jiwa". Berdasarkan data tersebut, dapat dilihat bahwa secara umum kaum perempuan mendominasi kuantitas penduduk Negara Republik Indonesia ini. Hal ini menunjukkan akses perempuan untuk lebih terlibat dalam lapangan kerja di bidang publik, juga sangat besar. Meskipun dalam realita, keberpihakan sering 
terjadi ketimpangan.

Masih cukup kentara adanya diskriminasi dalam akses publik. Kita bisa berasumsi bahwa setelah menamatkan sekolah, maka perempuan menikah dan lebih sibuk dengan urusanurusan domestik. Ini menjadi lebih parah jika dihubungkan dengan semakin terbatasnya akses penguasaan sumber daya di tingkat domestik dengan semakin memudarnya nilainilai kultural masyarakat pada masa lalu (Khaidir, A., 2005: 3).

Keadaan lain memperlihatkan, telah terjadi rendahnya otonomi perempuan. Otonomi perempuan dimaksudkan sebagai perempuan yang otonom, independen, dan mandiri dalam segala hal termasuk tentang tubuh dan kesehatannya. Rendahnya otonomi perempuan terhadap tubuhnya tampak pada besarnya jumlah Angka Kematian Ibu (AKI) di Indonesia. Naqiyah, N., (2005: 2), dengan mengutif dari http/www.yahoo.com. 14 Februari 2003 menyebutkan bahwa: "...Penyebab tingginya AKI, antara lain: pertama kurangnya akses kesehatan bagi perempuan, kedua kurangnya informasi, ketiga aborsi yang tidak aman, keempat pendarahan, kelimapendidikan rendah, keenam kurangnya kesadaran hak reproduksi, dan ketujuh 50\% ibu hamil terkena anemia dan kurang gizi".

UNESCO merekomendasikan pentingnya persamaan hak dan kesempatan bagi perempuan pada bidang pendidikan memasuki abad XXI. Menurutnya UNESCO, beberapa tujuan fundamental masyarakat internasional tentang persamaan akses oleh perempuan atas pendidikan untuk menghapuskan illiteracy bagi perempuan dan perbaikan akses untuk perempuan terhadap pelatihan keterampilan, sains dan teknologi pendidikan, serta pendidikan berkelanjutan" (Delors dalam Anwar, 2007: 93).

Strategi pengembangan perempuan, meliputi perhatian ditujukan untuk peningkatan kesejahteraan perempuan yang tergolong dalam kelompok masyarakat berpenghasilan rendah, untuk mendapat kesempatan yang lebih besar dalam menuntut pendidikan pasca pendidikan dasar, mendorong makin ikut berperannya perempuan dalam mengembangkan dan memafaatkan kemajuan ilmu dan teknologi bagi penyusunan rencana dan pelaksanaan program peningkatan kedudukan dan peranan perempuan secara lintas sektoral, menyusun program khusus yang diperuntukan bagi perempuan, 
agar dapat mengejar ketinggalannya dari kaum pria di berbagai bidang, meningkatkan kegiatan pendidikan bagi perempuan, baik kegiatan sektoral maupun kegiatan khusus peranan perempuan, dan mengupayakan perluasan kesempatan kerja dan berusaha di sektor formal dan informal dengan meningktakan pengetahuan, keterampilan, kesejahteraan dan produktivitas kerja serta peningkatan perlindungan kerja bagi perempuan.

Beberapa program pengembangan perempuan yang telah dilakukan di Indonesia diantaranya PKK (Pendidikan Kesejahteraan Keluarga) yang dikenal dengan sepuluh programnya: pertama penghayatan dan pengamalan Pancasila, kedua gotong royong,ketiga pangan, keempat sandang, kelima Perumahan dan tata laksana rumah tangga, keenam pendidikan dan keterampilan, ketujuh kesehatan, kedelapan pengembangan kehidupan berkoperasi, kesembilan kelestarian lingkungan hidup, dan sepuluh Perencanaan sehat. Selain program PKK, juga terdapat POSYANDU (Pos Pelayanan Terpadu) untuk BALITA, juga terdapat kegiatan pendidikan bagi perempuan (ibu-ibu) berupa pembinaan anak dan pola hidup sehat. Organisasi Dharma Wanita yang menghimpun istri pegawai negeri sipil, yang tersebar diseluruh instansi pemerintah dari pusat sampai ke Kecamatan. Organisasi Dharma Pertiwi yang menghimpun istri para pajurit TNI, Organisasi Patayat Nahdatul Ulama, Aisiyah. Bagi generasi muda terdapat Nasyiatul Aisiyah, IPPNU, KOHATI, dan berbagai organisasi kepemudaan lainnya yang anggotanya juga terdapat perempuan. Dalam bidang media massa, juga diadakan siaran pedesaan yang diperuntukan bagi masyarakat tani, mahasiswa KKN. Di tingkat desa sendiri ada kelompok akseptor, dan kelompok arisan yang dibentuk atas prakarsa dan swadaya masyarakat setempat (Anwar, 2007: 96).

Dalam mengantisipasi rendahnya tarap hidup keluarga, maka selain perlunya motivasi peran serta perempuan untuk meningkatkan upaya penanggulangan permasalahan pemenuhan kebutuhan hidup keluarga, juga perlunya ditingkatkan lagi bantuan teknik keterampilan dan pengetahuan yang berkaitan dengan komponen latihan dan bimbingan dapat berperan sebagai upaya peningkatan pengetahuan, keterampilan, dan sikap kewiraswastaan para perempuan melalui lembaga-lembaga sosial ditingkat desa. Beberapa kajian mengungkapkan bahwa faktor ekonomi merupakan alasan yang dikemukakan perempuan untuk mencari nafkah, dan semakin rendah status sosial 
perempuan maka semakin besar kemungkinan mereka untuk bekerja. Dalam hal ini lebih parah lagi bagi istri golongan berpenghasilan rendah cenderung lebih berperan dalam memperoleh penghasilan keluarga.

Pemerintah Indonesia melalui program-programnya di bidang Pendidikan Luar Sekolah (PLS), yang semakin hari semakin dipacu untuk tumbuh dan berkembang, berupaya mengadakan pelatihan-pelatihan di berbagai bidang keterampilan sebagai usaha untuk membuka seluas-luasnya kesempatan belajar bagi masyarakat khususnya bagi mereka yang kurang beruntung yang tidak dapat melanjutkan ke jenjang sekolah lebih tinggi / anak-anak putus sekolah.

Kursus dan pelatihan-pelatihan diselenggarakan bagi masyarakat yang memerlukan bekal pengetahuan, keterampilan, kecakapan hidup, dan sikap untuk mengermbangkan diri, mengembangkan profesi, bekerja, usaha mandiri, dan/atau melanjutkan pendidikan kejenjang yang lebih tinggi. Salah satu usaha sektor jasa yang potensial untuk berkembang dan tampaknya selalu dibutuhkan dari waktu ke waktu seiring kemajuan zaman dan kompleksitas kehidupan masyarakat adalah usaha jasa Tata Rias Pengantin.

Kenyataan dilapangan menunjukkan bahwasanya keterampilan dibidang Tata Rias Pengantin mempunyai prospek yang marketable dan dibutuhkan semua kalangan masyarakat, hal ini berkaitan erat dengan fungsi Tata Rias Pengantin sebagai kebutuhan utama bagi keluarga yang menyelenggarakan syukuran pesta pernikahan putra-putrinya. Dimana diketahui bahwa pernikahan pasangan manusia (pasangan pengantin) adalah hal alamiah terjadi dalam kurun perkembangan kehidupan manusia umumnya.

Pelatihan Profesi Bidang Tata Rias Pengantin merupakan salah satu bentuk pendidikan yang diselenggarakan melalui jalur PLS dengan mengutamakan pembekalan keterampilan guna meningkatkan kecakapan hidup bagi masyarakat, yang berguna untuk kepentingan diri pribadinya maupun bisa di manfaatkan bagi kepentingan dunia kerja dan profesinya.

Standarisasi dan sertifikasi suatu keterampilan untuk mendapatkan legalitas atau pengakuan sudah menjadi keharusan bagi masyarakat diera global ini. Untuk itu 
Lembaga Kursus dan Pelatihan ( LKP ) yang berperan aktif didalamnya selayaknya mengikuti persyaratan ini. Lembaga-lembaga yang bersangkutan harus menyiapkan dan membekali warga belajarnya dengan keterampilan yang bersertifikasi dan mendapat pengakuan global, termasuk dalam bidang keahlian keterampilan Tata Rias Pengantin sebagai modal untuk memperbaiki kualitas hidup masyarakat agar lebih baik dengan membuka lapangan kerja atau berusaha hidup secara mandiri.

Berdasarkan hasil identifikasi terhadap warga belajar pelatihan Tata Rias Pengantin Sunda Putri di Lembaga Kursus dan Pelatihan ( LKP ) MUSTIKA diketahui bahwa mereka merupakan warga masyarakat yang benar-benar berminat dan membutuhkan pelatihan Tata Rias Pengantin termasuk dari kalangan pegawai, pelajar, mahasiswa dan lain sebagainya.

Penyelenggaraan pelatihan keteramplan Tata Rias Pengantin di Sunda Putri ( LKP ) MUSTIKA dimaksudkan: Memberi bekal pengetahuan, keterampilan dan sikap kemandirian serta jiwa kewirausaan warga belajar menjalankan kehidupannya, atau berusaha mandiri membuka lapangan kerja. Memberi bekal pengetahuan dan keterampilan berusaha secara profesional sehingga warga belajar memperoleh pekerjaan dengan penghasilan yang layak dan akhirnya memberi danpak meningkatkan kesejahteraan kehidupan warga belajar secara ekonomi dan sosial.

\section{KAJIAN TEORI}

Kata efektif berasal dari bahasa Inggris, yaitu effectif yang berarti berhasil atau sesuatu yang dilakukan berhasisl dengan baik. Efektivitas selalu terkait dengan hubungan antara hasil yang diharapkan dengan hasil yang sesungguhnya dicapai. Efektivitas mengandung arti keefektifan (efectivenes) penggaruh/efek keberhasilan atau kemanjuran. Muasaroh menjelasksan efektivitass adalah suatu program yang dapat dilihat dari aspek-aspek antara lain : pertama aspsek tugas atau fungsi, kedua aspek rencana atau program, ketiga aspek ketentuan dan peraturan dan keempat aspsek tujuan atau kondisi ideal.

Pemerintah, masyarakat dan keluarga sebagai penanggung jawab penyelenggaraan pendidikan dituntut untuk mampu menyelenggarakan suatu sistem pendidikan yang dapat menopang kebutuhan yang dirasakan masyarakat. Pendidikan yang diberikan 
diharapkan mampu mempersiapkan dan meningkatkan mutu sumber daya manusia yang ada di masyarakat, baik melalui pendidikan persekolahan maupun Pendidikan Luar Sekolah. Kedua jalur pendidikan tersebut keberadaannya saling melengkapi sehingga seluruh komponen masyarakat mampu merasakan sentuhan pendidikan yang akan bermanfaat bagi kehidupannya. Tingginya tuntutan pendidikan menyebabkan kedua jalur pendidikan tersebut harus memberikan pelayanan yang mampu memenuhi segala tuntutan pendidikan masyarakat. Pendidikan Luar Sekolah sebagai jalur yang dirasakan sebagai penunjang pendidikan yang tidak diperoleh dan bahkan tidak sempat mengenyam pendidikan persekolahan. Perkembangan Pendidikan Luar Sekolah yang dewasa ini lebih dikenal dengan pendidikan non formal merupakan salah satu pendidikan yang ikut bertanggung jawab dalam mencerdaskan kehidupan bangsa dan mendayagunakan potensi sumber-sumber daya manusia yang ada, harus dapat menampilkan peranannya untuk membatasi kebutuhan masyarakat yang haus untuk belajar. Pendidikan Luar Sekolah adalah pendidikan yang teratur, dilakukan secara sadar tetapi tidak terlalu terikat oleh peraturan-peraturan yang ketat seperti layaknya pendidikan sekolah, diantaranya yaitu melalui kursus-kursus, penataran, penyuluhan dan lain-lain.

Peran SDM dalam organisasi atau perusahaan mempunyai arti yang sama pentingnya dengan pekerjaan itu sendiri, mengingat pentingnya peran Sumber Daya Manusia dalam organisasi atau perusahaan, SDM sebagai faktor penentu organisasi atau perusahaan maka kompetensi menjadi aspek yang menentukan keberhasilan organisasi atau perusahaan. Dengan Kompetensi yang tinggi yang dimiliki oleh SDM dalam suatu organisasi atau perusahaan tentu hal ini akan menentukan kualitas SDM yang dimiliki yang pada akhirnya akan menentukan kualitas kompetitif perusahaan itu sendiri. Konsep kompetensi sebenarnya bukan sesuatu yang baru. Menurut Organisasi Industri Psikologi Amerika (Mitrani, Palziel and Fitt, 1992 : 14) gerakan kompetensi telah dimulai pada tahun 1960 dan awal 1970.

Apakah yang dimaksud dengan Kompetensi? Menurut Spencer and Spencer, (1993 : 9) Kompetensi adalah sebagai karakteristik yang mendasari seseorang dan berkaitan dengan efektifitas kinerja individu dalam pekerjaannya (an underlying characteristic's of an individual which is causally related to criterion - referenced effective and or superior 
performance in a job or situation). Underlying Characteristics mengandung makna kompetensi adalah bagian dari kepribadian yang mendalam dan melekat kepada seseorang serta perilaku yang dapat diprediksi pada berbagai keadaan dan tugas pekerjaan. Causally Related memiliki arti kompetensi adalah sesuatu yang menyebabkan atau memprediksi perilaku dan kinerja. Criterion Referenced mengandung makna bahwa kompetensi sebenarnya memprediksi siapa yang berkinerja baik, diukur dari kriteria atau standar yang digunakan.

Menurut Poerwadarminta (1993:518), pelatihan merupakan salah satu bentuk satuan Pendidikan Luar Sekolah yang memerlukan fungsi perencanaan. Secara operasional dirumuskan bahwa pelatihan adalah suatu proses yang meliputi serangkaian tindak atau upaya yang dilaksanakan dengan sengaja dalam bentuk pemberian bantuan kepada peserta pelatihan yang dilakukan oleh tenaga profesional pelatihan dalam satuan waktu yang bertujuan untuk meningkatkan kemampuan peserta dalam bidang pekerjaan tertentu guna meningkatkan efektifitas dan produktifitas dalam suatu organisasi.

Pelatihan/ training adalah pembelajaran pengembangan indivudial yang sifatnya mendesak karena adanya kebutuhan sekarang (Anwar, 2004: 163). Dengan demikian, pembelajaran yang dilaksanakan sesuai dengan kebutuhan di lapangan disebut pelatihan.

Pendapat lain menyatakan bahwa "Pelatihan adalah usaha berencana yang diselenggarakan supaya dicapai penguasaan keterampilan, pengetahuan, dan sikap yang relevan dengan kebutuhan peserta pelatihan" (Hidayat dan Syamsulbahri, 2001: 169). Secara praktis, pelatihan menurut Sikula (Suryana Sumantri, 2001: 2) merupakan proses pendidikan jangka pendek yang menggunakan prosedur yang sistematis dan terorganisasi. Peserta pelatihan itu akan mendapatkan pengetahuan dan keterampilan untuk tujuan-tujuan tertentu.

Dasar penyelenggaraan pelatihan mengacu pada beberapa konsep. Konsep-konsep tersebut dapat diuraikan sebagai berikut : Pertama, pelatihan adalah suatu proses. Pelatihan merupakan suatu fungsi manajemen yang perlu dilaksanakan secara terus menerus dalam rangka pembinaan ketenagaan dalam suatu organisasi. Secara spesifik, 
proses latihan itu merupakan serangkaian tindakan atau upaya yang dilaksanakan secara berkesinambungan, bertahap dan terpadu. Tiap proses pelatihan harus terarah untuk mencapai tujuan tertentu terkait dengan upaya pencapaian tujuan organisasi. Itu sebabnya, tanggung jawab penyelenggaraan pelatihan terletak pada tenaga lini dan staf. Selanjutnya, Pelatihan dilaksanakan dengan sengaja. Unsur kesengajaan ini ditandai oleh adanya suatu rencana yang lengkap dan menyeluruh yang disusun secara tepat dan rinci. Perencanaan pelatihan berfungsi sebagai pegangan dalam penyelenggaraan pelatihan, acuan untuk mengontrol keterlaksanaan pelatihan dan alat untuk menilai keberhasilan program pelatihan secara menyeluruh. Kesengajaan membutuhkan pemikiran yang matang dan berdasarkan data/informasi yang akurat dari berbagai sumber yang relevan. Tata Rias Pengantin Sunda Putri merupakan salah satu dari keaneka ragaman budaya tata rias pengantin di Indonesia, walaupun saat ini sudah banyak bermunculan ahli tata rias pengantin Sunda, yang berdomisili selain di daerah Parahiyangan tetapi juga didaerah lain di Indonesia, hal ini menunjukkan bahwa Tata Rias Pengantin Sunda Putri sudah banyak diminati dan patut dilestarikan dan dikembangkan. Salah satu daya tarik keunikan dari Tata Rias Pengantin Sunda Putri adalah pada riasan wajah pengantinnya yang berbeda dengan Tata Rias Pengantin dari daerah lain seperti warna bayangan matanya (yang masih menggunakan warna-warna pakem).

Menurut Agani (Yanto, 2010: 6) tata rias bagi seorang pengantin mencakup apa yang disebut dengan tata rias wajah, tata rias rambut, tata busana dan perhiasan. Tujuan dari merias wajah adalah untuk mempercantik wajah seseorang. Berhubung tidak ada suatu pola tertentu yang dapat digunakan untuk merias wajah, maka tindakan yang utama ialah, menonjolkan bagian wajah yang bagus dan menyembunyikan bagian-bagian yang kurang indah dengan keterampilan pengolesan kosmetik. Oleh karena itu penata rias harus memahami serta menguasai teori dan praktek kosmetologi, disamping mengenal bentuk muka, mata, hidung, dan warna kulit dan kombinasi untuk riasan wajah.

\section{METODE PENELITIAN}

\section{Jenis Penelitian}

Penelitian ini dilakukan dengan metode deskriptif kualitatif yaitu dengan cara memandang objek penelitian sebagai suatu sistem, yaitu artinya objek kajian dapat 
dilihat sebagai satuan yang terdiri dari unsur yang saling terkait dan mendeskripsikan fenomena yang ada.

\section{Subyek Penelitian}

Subyek penelitian satu orang Pengelola, satu orang instruktur dan empat warga belajar LKP Mustika yang aktif mengikuti pembelajaran

\section{Setting dan Waktu Penelitian}

Penelitian ini dilakukan di LKP Mustika dan di rumah warga belajar dengan pertimbangan peneliti dapat mengamati secara langsung kegiatan pembelajaran dan kegiatan peserta didik pasca pembelajaran Penelitian dilaksanakan pada bulan November 2018 sampai dengan bulan April 2018.

\section{Teknik Pengumpulan Data}

Penelitian ini bersifat deskriptif berupa dokumen pribadi, catatan harian, catatan lapangan, ataupun ucapan responden dari hasil wawancara. Instrumen dalam penelitian ini yaitu peneliti sendiri yang dibantu oleh observasi, pedoman wawancara, dan studi dokumentasi. Teknik pengumpulan data yang digunakan adalah observasi, wawancara dan dokumentasi.

\section{Teknik Analisis Data}

Tahapan analisis data dalam penelitian ini yaitu reduksi data, display data dan penarikan kesimpulan. Reduksi data dimaksudkan dengan merangkum data, memilih hal-hal pokok, disusun secara sistematik display data atau penyajian data bertujuan untuk memudahkan peneliti memahami hasil penelitian yang telah didapatkan. Data tersebut dibandingkan dan dihubungkan dengan yang lainnya, sehingga mudah ditarik kesimpulan sebagai jawaban dari setiap permasalahan yang ada.

\section{HASIL DAN PEMBAHASAN}

\section{HASIL}

Hasil wawncara dengan Instruktur bahwa efektifitas pelatihan berhasil diwujudkan dalam proses penyelenggaraan pelatihan keterampilan Tata Rias Pengantin Sunda Putri di LKP MUSTIKA. Hal ini diketahui dengan terpenuhinya kriteria keberhasilan dalam sebuah konsep pelatihan/pembelajaran. Kriteria keberhasilan program pelatihan 
ketermpilan Tata Rias Pengantin Sunda Putri itu berhubungan dengan dua hal, yaitu:

a. Dari segi proses (by process), dimana hal ini berkenaan dengan keberhasilan pada: Perencanaan yang sistematik, Kegiatan belajar yang diikuti secara wajar, tanpa paksaan, Penggunaan metode dan media yang sesuai, Kemampuan warga belajar mengontrol diri sendiri (self kontrol), Keterlibatan semua warga belajar, Suasana menyenangkan, Keberadaan sarana belajar yang memadai.

b. Kriteria keberhasilan dari segi hasil (by product), yakni keberhasilan keadaan hal berikut: Perubahan tingkah laku warga belajar secara menyeluruh (kognitif, afektif, psikomotor), Hasil pembelajaran berdaya guna bagi warga belajar untuk diaplikasikan dalam kehidupannya, Hasil pembelajaran tahan lama diingat oleh warga belajar, Proses perubahan diyakini berasal dari proses pengajaran.

Tabel 1. Data Warga Belajar LKP MUSTIKA KABUPATEN CIANJUR

\begin{tabular}{clllc}
\hline NO & \multicolumn{1}{c}{ NAMA } & TMT TGL LAHIR & PENDIDIKAN & L/P \\
\hline 1. & Endah Asri R & Cianjur, 04/5/1986 & SMA & P \\
\hline 2. & Euis Ita Setiawati & Cianjur, 22/2/1989 & SMA & P \\
\hline 3. & Eva Rubaedah & Cianjur, 26/6/1968 & SMA & P \\
\hline 4. & Faridatul Bahiyah & Cianjur 24/08/1992 & SMA & P \\
5. & Julaeha & Cianjur, 8/5/1978 & SMA & P \\
\hline 6. & Maelani Ulfah & Cianjur, 2/5/1987 & SMA & P \\
\hline \multicolumn{2}{l}{ Sumber: Profil LKP MUATIKA } & & \\
\hline
\end{tabular}

\section{PEMBAHASAN}

Berdasarkan hasil pengamatan secara langsung proses pembelajaran ketrampilan tata rias pengantin Sunda Putri ada beberapa peserta didik yang terlihat meningkat pengetahuannya, dari sebelumnya rendah setelah mengikuti pelatihan tata rias pengantin Sunda terlihat meningkat. Hal ini sesuai teori S. Handayaningrat dalam bukunya berjudul "Pengantar Studi dan Administrasi" mengemukakan bahwa proses adalah seranglaian tahapan kegiatan mulai dari menentukan sasaran sampai tercapaiknya tujuan. (1988 : 20) dan efektifnya pembelajaran yang dikemukakan oleh Muasaroh (2010 :78) efektif berasal dari bahasa Inggris, yaitu effectif yang berarti 
berhasil atau sesuatu yang dilakukan berhasisl dengan baik. Efektivitas selalu terkait dengan hubungan antara hasil yang diharapkan dengan hasil yang sesungguhnya dicapai. Efektivitas mengandung arti keefektifan (efectivenes) penggaruh/efek keberhasilan atau kemanjuran.

Peran SDM dalam organisasi atau perusahaan mempunyai arti yang sama pentingnya

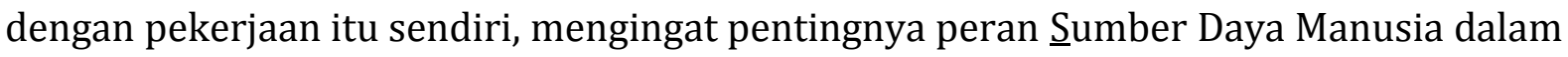
organisasi atau perusahaan, SDM sebagai faktor penentu organisasi atau perusahaan maka kompetensi menjadi aspek yang menentukan keberhasilan organisasi atau perusahaan. Dengan Kompetensi yang tinggi yang dimiliki oleh SDM dalam suatu organisasi atau perusahaan tentu hal ini akan menentukan kualitas SDM yang dimiliki yang pada akhirnya akan menentukan kualitas kompetitif perusahaan itu sendiri. Konsep kompetensi sebenarnya bukan sesuatu yang baru. Menurut Organisasi Industri Psikologi Amerika (Mitrani, Palziel and Fitt, 1992 : 14).

Menurut Spencer and Spencer, (1993 : 9) Kompetensi adalah sebagai karakteristik yang mendasari seseorang dan berkaitan dengan efektifitas kinerja individu dalam pekerjaannya (an underlying characteristic's of an individual which is causally related to criterion - referenced effective and or superior performance in a job or situation). Underlying Characteristics mengandung makna kompetensi adalah bagian dari kepribadian yang mendalam dan melekat kepada seseorang serta perilaku yang dapat diprediksi pada berbagai keadaan dan tugas pekerjaan. Causally Related memiliki arti kompetensi adalah sesuatu yang menyebabkan atau memprediksi perilaku dan kinerja

Pendapat lain menyatakan bahwa "Pelatihan adalah usaha berencana yang diselenggarakan supaya dicapai penguasaan keterampilan, pengetahuan, dan sikap yang relevan dengan kebutuhan peserta pelatihan" (Hidayat dan Syamsulbahri, 2001: 169). Secara praktis, pelatihan menurut Sikula (Suryana Sumantri, 2001: 2) merupakan proses pendidikan jangka pendek yang menggunakan prosedur yang sistematis dan terorganisasi. Peserta pelatihan itu akan mendapatkan pengetahuan dan keterampilan untuk tujuan-tujuan tertentu.

Menurut Agani (Yanto, 2010: 6) tata rias bagi seorang pengantin mencakup apa yang disebut dengan tata rias wajah, tata rias rambut, tata busana dan perhiasan. Tujuan dari 
merias wajah adalah untuk mempercantik wajah seseorang. Berhubung tidak ada suatu pola tertentu yang dapat digunakan untuk merias wajah, maka tindakan yang utama ialah, menonjolkan bagian wajah yang bagus dan menyembunyikan bagian-bagian yang kurang indah dengan keterampilan pengolesan kosmetik. Oleh karena itu penata rias harus memahami serta menguasai teori dan praktek kosmetologi, disamping mengenal bentuk muka, mata, hidung, dan warna kulit dan kombinasi untuk riasan wajah.

\section{KESIMPULAN}

Penelitian ini secara umum telah mencapai tujuannya yaitu memperoleh gambaran Efektifitas Pelatihan Tata Rias Pengantin Sunda di LKP Mustika Cianjur. Pelatihan ini dikembangkan mengacu pada teori dan metode program Pendidikan Masyarakat. Pendidikan Masyarakat sebagai proses pemberdayaan, mengandung makna bahwa program-program pendidikan ini harus ditunjukan untuk mendidik masyarakat agar mampu mendidik diri mereka sendiri atau membantu masyarakat agar mampu menbantu diri mereka sendiri dalam rangka menciptakan masyarakat yang mandiri, berswadaya, dan berdaya.

\section{DAFTAR PUSTAKA}

Agani , Yanto, (2010). Tata Rias Pengantin. Jakarta. Prenada Media Grup Anwar. (2007). Perempuan Indonesia. Bandung :Yayasan Pembangunan Indonesia. Delors. (2007). Nilai-nilai Kultural Masyarakat. Jakarta : Libri.

Hidayat dan Syamsulbahri. (2001). Konsep Pelatihan. Jakarta. Grasindo.

Khaidir, A. (2005). Nilai-nilai Kultural Masyarakat. Jakarta : PT. Gramedia Pustaka Utama. Mitrani,Palziel and Fitt. (1992). Kompetensi. Jakarta : PT Gramedia Pustaka.

Muasaroh (2010) Efektivitass : Fungsi dan Tujuan. Jakarta. Pustaka Ilmu Naqiyah, N. (2005). Penyebab tingginya AKI .htt/www.yahoo.com

Nandang Rukanda. (2016). Jurnal : Efektivitas Pelatihan Tata Rias Pengantin Sunda Putri Dalam Rangka Pemberdayaan Perempuan Di Lembaga Pendidikan Keterampilan Tisaga Caterias Kota Cimahi

Poerwadarminta. (1993). Kompetensi Pembelajaran. Jakarta : Lubuk Agung.

S. Handayaningrat. (1988). Pengantar Studi dan Administrasi. Jakarta. Raja Grafindo Persada

Suryana Sumantri. (2001). Pendidikan Jangka Pendek. Jakarta : Bumi Aksara. 
Spencer and Spencer, (1993). Kompetensi dalam Kinerja. Bandung. Tarsito 